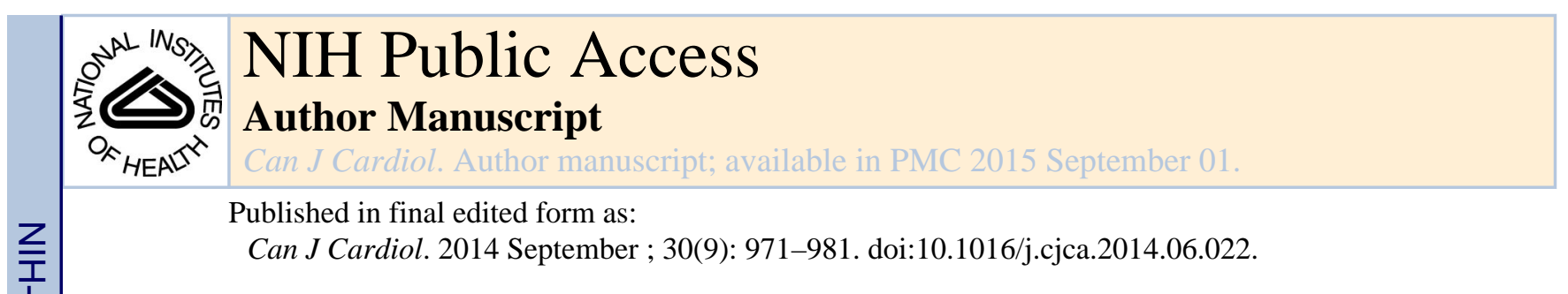

\title{
Basic Mechanisms of Mitral Regurgitation
}

Jacob P. Dal-Bianco, MD, Instructor in Medicine, Massachusetts General Hospital, Harvard Medical School, 55 Fruit Street, Yawkey 5B, Boston, MA, 02114, jdalbianco@partners.org

Jonathan Beaudoin, MD, and

Institut Universitaire de Cardiologie et de Pneumologie de Québec, Department of Cardiology, Quebec City, Quebec, Canada, jonathan.beaudoin@criucpq.ulaval.ca

Robert A. Levine, MD

Professor of Medicine, Massachusetts General Hospital, Harvard Medical School, Cardiac Ultrasound Laboratory, 55 Fruit Street, Yawkey 5E, Boston, MA, 02114, rlevine@partners.org, Office tel: 617724 1995, Office fax: 6176431616

\section{Abstract}

Any structural or functional impairment of the mitral valve (MV) apparatus that exhausts MV tissue redundancy available for leaflet coaptation will result in mitral regurgitation (MR). The mechanism responsible for MV malcoaptation and MR can be dysfunction or structural change of the left ventricle, the papillary muscles, the chordae tendineae, the mitral annulus and the MV leaflets. The rationale for MV treatment depends on the MR mechanism and therefore it is essential to identify and understand normal and abnormal MV and MV apparatus function.

\section{Keywords}

mitral regurgitation; mitral valve; mitral annulus; papillary muscles; chordae tendineae

\section{Introduction}

Normal mitral valve (MV) function is dependent on the integrity of the MV apparatus and the harmonious interplay of its main components - the mitral annulus (MA), the MV leaflets, the chordae tendineae, and the LV wall with its attached papillary muscles (PMs) (Figure 1 A, B). This spatially and temporally finely tuned system maintains the MV leaflets within the LV preventing prolapse, and maintains them beneath LV outflow tract (LVOT) flow and taut, preventing systolic anterior motion (SAM). Adequate MV leaflet closure and

C2014 Canadian Cardiovascular Society. Published by Elsevier Inc. All rights reserved.

Correspondence to: Robert A. Levine.

Publisher's Disclaimer: This is a PDF file of an unedited manuscript that has been accepted for publication. As a service to our customers we are providing this early version of the manuscript. The manuscript will undergo copyediting, typesetting, and review of the resulting proof before it is published in its final citable form. Please note that during the production process errors may be discovered which could affect the content, and all legal disclaimers that apply to the journal pertain.

Financial Disclosure: The authors have nothing to disclose.

All authors have participated in the work and have reviewed and agree with the content of the article. 
coaptation depend on the balance of systolic leaflet tethering vs LV closing forces and leaflet size [1]. Tethering forces are dependent on and transmitted via the LV wall - PM chordae system, and closing forces reflect the pressure generated by the contracting LV [24] (Figure 1A). MV dysfunction is relatively uncommon in patients younger than 65 years [5], but structural and / or functional impairment of any MV apparatus components can unsettle the tethering force - closing force balance and result in mitral regurgitation (MR) [2-4].

\section{Mitral Valve Apparatus}

The MV has anterior and posterior leaflets and variable commissural scallops. The leaflet bases circumferentially insert into the mitral annulus, and the ventricular leaflet body and edges are connected to the PMs and LV wall via chordae (Figure 1B, C). The leaflet cross sectional structure is trilaminar and each layer's extracellular matrix (ECM) has unique characteristics and biomechanical properties important to the normal function of the MV. On the atrial side, the atrialis layer is rich in subendothelial elastic proteins that buffer leaflet stretch during systole. The atrialis is covered by endotheliumin continuum with the LA. Towards the leaflet core, the spongiosa layer contains hydrophilic proteins that act as cushion-like coaptation zone shock absorbers and therefore promote a tight MV seal. Facing the ventricular side, the fibrosa / ventricularis layer is characterized by a sub-endothelial collagen fiber network aligned to transmit and spread the LV closure / chordal force optimally towards the mitral annulus. Valve interstitial cells can be found in all layers and have an important role in maintaining leaflet homeostasis. Mostly quiescent in the normal adult leaflets, these interstitial cells can become activated in response to mechanical stress or injury to promote ECM remodeling [6]. The anterior leaflet is larger (4-7 vs 2-3 $\mathrm{cm}^{2}$ ), longer (18-24 vs 11-14 $\mathrm{mm}$ ) and usually thicker than the posterior leaflet and is trapezoid / dome-shaped [7-12]. It shares a rigid fibrous tissue continuity with the noncoronary cusp of the aortic valve (Figure $1 \mathrm{~B}, \mathrm{C}$ ). The posterior leaflet is crescentic-shaped with short radial length [12] and a long circumferential base that is attached to the posterior MA (Figure $1 \mathrm{~B}$, C). The MA is a non-planar saddle shaped tissue structure that interconnects the LA, the LV and the mitral leaflets [13,14] (Figure 1 B, C; Figure $2 \mathrm{~A}$ ). The MA is innervated and supplies blood vessels and nerve fibers to the attached leaflet bases $[15,16]$. The anterior portion of the MA is continuous with the rigid aortic annulus and is the elevated (most atrial) "horn" of the saddle shape [13, 17] (Figure 2 A). The posterior MA includes the low points of the saddle (most ventricular), close to the lateral and medial commissures and the posterior saddle horn (Figure $2 \mathrm{~A}$ ). The average MA area in healthy subjects is $\sim 10 \mathrm{~cm}^{2}[10$, 18-21]. The flexible posterior MA allows for systolic apical bending along a commissural axis $[17,22]$. This mechanism, in combination with the planar kidney-bean and horizontal saddle-shape configuration allows the MA to sphincter-like shrink in area by $\sim 20-42 \%$ from diastole to systole [19-21, 23, 24], which reduces leaflet tissue stress and is important to maintain coaptation (Figure $2 \mathrm{~B}, \mathrm{C}$ ) [25-30]. The chordae tendineae originate from the PM heads and are fibrous strings composed of an interfacing, tightly linked collagen and elastin network. They insert fan5 like into the anterior, posterior and commissural leaflets and dampen the PM - leaflet force transmission (Figure 1 B) [31, 32]. Chordae can be distinguished by leaflet location insertion as primary and secondary. Primary (marginal) 
chordae attach to the leaflet free edges, are thinner and have limited extensibility due to higher collagen fibril density and reduced crimping [33]. These characteristics ensure a stable systolic coaptation location. Secondary (basal) chordae insert into the central anterior and posterior leaflet bodies [34] are thicker and have more tightly crimped collagen that makes them more extensible [33]. The PMs are labeled by their projected relationship to the mitral commissures as lateral and medial [11] (Figure 1 B,C). Their bodies originate from the apical $1 / 3$ of the LV and protrude finger-like into the cavity [35] (Figure $1 \mathrm{~A}, \mathrm{~B}$; Figure 3). In the majority of cases the lateral PM has a single head and dual blood supply from the left circumflex and left anterior descending coronary arteries. The medial PM has commonly 2 heads and is either supplied by the right or circumflex coronary artery based on dominance $[8,11,36]$. PM contraction maintains the spatial relationship between the MA and the PM heads during systole and prevents leaflet prolapse [37-39].

\section{Mitral Regurgitation Mechanism}

MR develops if the MV leaflets do not sufficiently cover the MA orifice throughout LV systole, and is commonly classified as primary MR - indicating leaflet pathology - or secondary MR in the setting of LV myocardial pathology. MR can also be functionally classified based on MV leaflet pliability and motion (Carpentier Classification) [40, 41]. To facilitate medical communication, MV leaflet malcoaptation and MR jet origin are commonly indicated by anterior (A) or posterior (P) leaflet and lateral (A1 / P1), central (A2 / P2) or medial scallop location (A3 / A3) [31] (Figure 1 C).

It is important to understand that significant MR regardless of etiology can prompt independent and ongoing LV and MV apparatus remodeling and start a vicious circle whereby reactive remodeling contributes to MR [4, 10,42]. An example is MA dilatation and dysfunction, which is rarely a primary cause for MR, but much more commonly a consequence of other MV or LV diseases. Significant MR is uncommon if the MV leaflet MA area ratio is larger than $\sim 1.5-2[8,10]$, but this ratio is in jeopardy once the MA dilates and loses its saddle shape and sphincter function [10, 19, 21, 24, 43]. MA remodeling additionally increases leaflet stress [25-30, 44]. MA flattening has also been described in myxomatous MV disease, associated with more severe MR and chordal rupture, potentially related to increased out-of-plane stresses [30, 45, 46]. MA remodeling has also been recently reported in patients with atrial fibrillation and MR, termed atrial functional MR [47, 48].

\section{Primary Mitral Regurgitation}

\section{1) Chordal Rupture / Papillary Muscle Rupture}

Elongation or rupture of marginal chordae due to degenerative tissue abnormalities, iatrogen, or endocarditis almost always lead to significant MR due to leaflet edge eversion (=flail leaflet; Figure 3 A) [49]. Secondary chordae rarely rupture, and due to their leaflet body insertion, are not critical to maintain coaptation. To the contrary, cutting secondary chordae is a strategy to potentially treat secondary MR when chordal tethering restricts coaptation (please see below). Due to its single coronary artery supply, the medial PM is at higher risk to necrose and rupture in myocardial ischemia and infarction. 
Treatment strategies-Chordal or PM rupture almost always results in flail leaflets and acute severe MR, with intermediate MR degrees with isolated rupture of structurally less important chords or an individual PM tip rather than a full head. Acute severe MR is a medical catastrophe that in the majority of patients leads to flash pulmonary edema and cardiogenic shock. The underlying etiology determines the mortality, which is up to $55 \%$ in patients presenting with acute MI [50]. Nonischemic chordal rupture in the setting of degenerative MV disease or endocarditis has a lower mortality rate, and the clinical presentation may be less dramatic if there was antecent MR and the LV and LA have adapted to MR hemodynamics. Since the underlying problem of acute severe MR is mechanical, surgical MV repair or replacement are the only sustainable treatment options. Pre- and afterload-reducing medical and interventional therapies (e.g. percutaneous LV assist device, Intra-aortic balloon pump) can be used as a bridge to potential surgical MV leaflet coaptation restoration. Transcatheter MV repair with a MitraClip (Abbott Laboratories, Abbott Park, Illinois) may become an alternative to openheart surgery if leaflet anatomy and underlying MR etiology are suitable and the risks for open-heart surgery prohibitive [51].

\section{2) Mitral Valve Prolapse}

Mitral valve prolapse (MVP) is defined as anterior, posterior or bileaflet MV billowing toward the left atrium by more than $2 \mathrm{~mm}$ above the anterior and posterior MA horns during LV systole, and affects about $2.5 \%$ of the general population [52, 53]. MV coaptation geometry is altered due to a combination of leaflet and chordal extensibility, redundancy and elongation, potentially combined with MA flattening and enlargement [30, 45, 46]; whether superior PM displacement or traction is cause or effect of prolapse is unclear [54, 55]. MR severity depends on the degree of leaflet malcoaptation; it can range from trace to severe and increases over time [56]. MVP is usually a manifestation of degenerative MV disease, and as such resulting MR is often termed degenerative MR (DMR). MVP is characterized by mainly two leaflet pathologies that have been described in the literature, although it is not known whether they are discrete etiologies or parts of a continuum: In the first, termed "Barlow's disease", the billowing leaflets are diffusely thickened, redundant and discolored. Bi-leaflet prolapse is common and patients tend to need MV intervention by age 50. Barlow leaflets are characterized by an altered trilaminar architecture, abnormal accumulation of myxomatous ECM, disordered collagen and elastin fibers and activated interstitial cells that express excessive levels of catabolic enzymes [57]. The other reported MVP phenotype is called "Fibroelastic deficiency" (FED) [12], in which the MV is in general thin to lucid except in flail leaflet portions, which may be due to secondary changes triggered by turbulent MR flow [58]. Patients with FED commonly present with ruptured chords and a variably flail posterior leaflet in their $6^{\text {th }}$ decade. FED leaflets are deficient in collagen, elastin and proteoglycans. MVP is associated with connective tissue syndromes, in particular collagen mutations (e.g. Ehlers-Danlos, Osteogenesis imperfecta) and Marfan syndrome, in which current knowledge suggests that abnormal fibrillin-1 leads to overexpression of transforming growth factor beta (TGF- $\beta$ ), an important regulator of MV leaflet ECM formation and remodeling $[59,60]$. Similar valve abnormalities can be seen in patients with mutation of TGF- $\beta$ receptors (Loeys-Dietz syndrome) [61]. Nonsyndromic MVP can be sporadic or familial, and appears to be transmitted via various genetic pathways and 
penetrance. Family MVP studies have suggested an autosomal dominant transmission and identified specific chromosomes [62-64]. Studies of X-linked forms of myxomatous valve disorders have revealed FLNA gene mutations $[65,66]$ that result in impaired filamin A, a protein vital to normal actin cytoskeleton structure and function that protects cells from mechanical stress [67].

Treatment strategies-Hemodynamically significant DMR is commonly considered to be at least moderate to severe, and lesser MR - unless in patients in need for open-heart surgery for other reasons - is usually clinically monitored and followed. Significant DMR is a mechanical problem of leaflet malcoaptation, and unless as a bridge to surgery or in inoperable patients, medical therapy has a rather limited role with poor long-term outcome (up to $8 \%$ yearly mortality; up to $10 \%$ yearly morbidity; up to $90 \%$ chance of need for surgery / death over 10 years) [68-70]. Surgical or transcatheter MV interventions on the other hand aim to restore effective MV leaflet coaptation by reducing leaflet redundancy, MA dimensions, and if needed, implanting artificial neo-chordae to restrain leaflet excursion. Suitable leaflet characteristics may allow leaflet free edge approximation at the MR site (edge-to-edge technique) by a stich (Alfieri stitch) [71] or a clip (MitraClip) [51]. Repair techniques aim to restore leaflet function while preserving the native valve and mechanical or tissue MV replacement is rarely needed in patients with MVP and a skilled surgeon [40]. Improving the natural history of chronic degenerative significant MR hinges on intervening at a time point that maximizes patient survival and minimizes disease and intervention morbidity. The evidence base supporting such an optimal intervention timepoint in chronic significant DMR is unfortunately, however, imperfect due to a lack of randomized and prospective studies. Currently, the AHA / ACC Valvular Heart Disease guidelines recommend that patients with symptomatic severe DMR (with a LV ejection fraction $(\mathrm{LVEF})>30 \%$ ) as well as asymptomatic patients who have an LVEF $\leq 60 \%$ or an LV end-systolic LV chamber dilatated $\geq 40 \mathrm{~mm}$ should have MV surgery with emphasis on MV repair of either the anterior or posterior leaflet when possible and durable as opposed to MV replacement (Class I Level B) [72]. This approach has been criticized for intervening too late, as patients with significant symptoms and LV dysfunction have worse postoperative outcome in terms of mortality and durability of MV repair [73]. Class IIa Level B MV surgery recommendations are for asymptomatic patients with severe DMR with 1) new onset of atrial fibrillation or 2) resting pulmonary hypertension $>50 \mathrm{mmHg}$ as long as there is a high likelihood of a successful and durable MV repair. An important and Class IIa Level $\mathrm{B}$ recommendation is to consider MV surgery in asymptomatic patients with severe DMR with preserved LV function and dimensions in whom the likelihood of a successful and durable repair without residual $\mathrm{MR}$ is $>95 \%$ with an expected mortality rate of $<1 \%$ when performed at a Heart Valve Center of Excellence [72]. This approach is supported by the progressive and dire natural history of chronic severe DMR when treated medically and decreased postoperative survival once significant symptoms or LV dysfunction develop [70, 73]. The long-term success of this strategy that ultimately restores life expectancy to normal is, however, absolutely dependent on a predictable, successful and durable MV repair [74, 75]; it is also worthwhile to point out that mainly patients over the age of 50 seem to benefit [75]. A recent guideline addition was the consideration of transcatheter MV repair in 
severely symptomatic patients with chronic severe DMR but prohibitive surgical risks and a reasonable life expectancy (the only FDA approved approach is the MitraClip) [72].

Besides surgical techniques, the routine intra-op MV surgical use of transesophageal echocardiography (TEE) has contributed significantly to predicting, guiding and assessing successful MV repair: TEE imaging can determine MV annuloplasty ring size by measuring the anterior leaflet length and required neo-chord lengths, which is especially helpful in less invasive MV repair [76]. TEE can predict post MV repair development of systolic anterior motion (SAM, see below) based on LV cavity size $<45 \mathrm{~mm}$ in end-diastole, aorto-mitral angle $<120$ degrees, MV leaflet coaptation-septum distance $<25 \mathrm{~mm}$, posterior leaflet height $>15 \mathrm{~mm}$ and basal septal diameter $\geq 15 \mathrm{~mm}[77,78]$. Transcatheter MV repair with a MitraClip would be close to impossible without TEE guidance.

\section{3) Leaflet Perforation}

Anterior or posterior MV leaflet perforation can be the result of trauma, but is most commonly due to localized tissue destruction from endocarditis. Besides primary MV endocarditis, AV endocarditis can directly extend towards the anterior MV leaflet via the anatomically shared fibrous trigone (Figure 1C) or be transmitted via the AV regurgitation blood jet.

Treatment strategies-Depending on the size and location of the MV leaflet perforation, potential endocarditis extent, and overall clinical presentation, such tissue defects can be closed with a pericardial patch.

\section{Secondary Mitral Regurgitation}

Functional or ischemic MR is the result of systolic leaflet restriction and tethering to displaced PMs in the setting of a distorted, remodeled LV (Figure $3 \mathrm{~B}$ ). LV remodeling can be global, with LV dilatation and increased sphericity [3,79-82], or localized, affecting mainly the PM - bearing LV walls [83]. LV remodeling that leads to outward apical / posterior / posterolateral PM displacement (Figure 3 B) [83-88] will increase the systolic PM heads - MA distance [89-92], which restricts MV leaflet closure motion and increases tethering forces. Leaflet coaptation is impaired and MR results [93]. In secondary MR, the MV leaflets are classically considered normal and to be innocent bystanders. Recent investigations, however, show significant MV leaflet tissue changes and adaptation [4, 10, 94-98]. Indeed, active leaflet growth and enlargement can occur in reaction to mechanical stretch, sometimes matching even severe LV dilatation to prevent secondary MR [4, 10, 42, $98,99]$. Reactivation of embryonic growth processes such as endothelial-to-mesenchymal transformation and mild TGF- $\beta$ expression in response to mechanical stretch have been shown in-vitro [100] and in-vivo in tethered leaflets [42]. Insufficient leaflet growth in the setting of heart failure is however frequent and secondary MR remains common. Preliminary data recently showed that excessive leaflet thickening can occur after myocardial infarction and is associated with subsequent MR [101], which is in accordance with previous work suggesting the presence of adverse fibrotic leaflet changes in secondary MR. These changes include abnormal matrix composition, increased collagen concentration and turnover and activation of valvular interstitial cells leading to stiffer valves, potentially 
impairing coaptation and contributing to MR [96, 97, 102]. These observations are currently challenging leaflet "normality" in secondary MR.

\section{Treatment strategies}

The aim of significant secondary MR therapy is to reduce apical and mitral annular leaflet tethering to restore MV leaflet tissue redundancy for effective MV coaptation. Every effort should be made to improve LV function by optimally treating coronary artery disease (medically / revascularization) [103-105], and cardiomyopathy and heart failure medically, if indicated by cardiac resynchronization therapy $[106,107]$ and potentially by gene / cell therapy [108-111]. Acknowledging the limited evidence, the current AHA / ACC Valvular Heart Disease guidelines recommend that MV surgery is reasonable in patients with chronic severe secondary MR who are undergoing coronary artery bypass grafting or aortic valve replacement (Class IIa Level C); MV surgery may be considered for severely symptomatic patients with chronic severe secondary MR (Class IIa Level B); MV repair may be considered for patients with chronic moderate secondary MR who are undergoing other cardiac surgery (Class IIa Level C) [72]. Surgical techniques besides current mitral annulus area reduction and / or MV repair / replacement [112] may target PM repositioning by addressing the LV shape [113-115], isolated PM approximation [116], chordal cutting [117120] and MV leaflet edge-to-edge approximation technique [71]. Therapy strategies that deal with the MV annulus alone but not apical leaflet tethering are often limited and result in recurrent MR [112, 121-124]; leaflet tethering can additionally be reduced, for example by cutting selected secondary chordae without deleterious effects on LV function [118-120, 125]. Transcatheter MV repair in symptomatic, at least moderate to severe secondary MR patients is currently studied in the Cardiovascular Outcomes Assessment of the MitraClip Percutaneous Therapy for Heart Failure Patients with Functional Mitral Regurgitation (COAPT) Trial. Although therapeutic strategies promoting compensatory MV leaflet growth with minimal fibrosis would be of interest, factors underlying valve tissue adaptation and remodeling are still poorly understood at this time.

\section{Hypertrophic Cardiomyopathy}

Hypertrophic cardiomyopathy (HCM) is morphologically characterized by significant LV hypertrophy in the absence of chronically elevated afterload or infiltrative diseases (e.g. cardiac amyloidosis) (Figure $3 \mathrm{C}$ double-arrow) [126]. In HCM, total PM muscle mass is doubled and the number of heads increased [127]. The PMs are anteriorly displaced (Figure $3 \mathrm{C}$ arrow) and the heads closer to each other [128, 129], which increases MV leaflet slack and positions the leaflets closer towards the LVOT. Larger and elongated MV leaflets additionally contribute to leaflet slack $[9,130]$. This PM - MV constellation favors a MV coaptation location more anteriorly and closer to the LVOT, which predisposes the anterior leaflet to being pushed into the LVOT by blood-flow drag forces (=systolic anterior motion (SAM) $[129,131-135]$. Subsequent LVOT narrowing increases the blood flow velocity above the leaflet and propagates SAM through airplane-like lift forces [136, 137]. MR will develop once anterior leaflet displacement interferes with MV leaflet coaptation (Figure $3 \mathrm{C}$ red lines) [138]. Frequent MV and PM anomalies predispose to SAM [139]. Mechanisms leading to leaflet growth in HCM are still poorly understood; paracrine effects coming from 
the abnormal myocardium, or mechanically induced growth secondary to turbulent or increased shear flow have been suggested; direct effects of gene defects / mutation on sarcomeric proteins are less likely as they do not appear to be expressed in the bulk of leaflet tissue [140].

\section{Treatment Strategies}

Since PM position is a major culprit, surgical or interventional septal reduction therapy does not always eliminate SAM [141, 142]. Additional effective repair strategies can include partial LV wall detachment of atypical anteriorly displaced PM insertions and trimming PM muscle mass [143], along with leaflet redundancy reduction, such as by an Alfieri stitch [144] or MitraClip [145].

\section{Rheumatic Heart Disease}

Rheumatic heart disease (RHD) can develop when T- \& B- cell guided autoimmune response triggered by an untreated streptococcus pharyngitis mistargets heart tissue (molecular mimicry) [146]. Streptococcal carbohydrate-directed antibodies recognize cardiac myosin and also target heart valve endothelium via the protein laminin. This prompts a local inflammatory response and exposure of collagen with development of autoantibodies against exposed collagen. Endothelial expression of vascular cell adhesion molecule-1 (VCAM-1) drives further immune cell leaflet infiltration. The accumulating cocktail of inflammatory cells and cytokines promotes a vicious cycle of valvular interstitial cell activation, fibrotic leaflet remodeling and interstitial neovascularization [146]. Significant MR is the predominant valvular pathology during the initial phase of rheumatic fever and carditis. The MR mechanism is anterior leaflet prolapse due chordal elongation and MA annular dilatation [147, 148]. In the initial disease phase the MV leaflets appear normal, which is in stark contrast to advanced rheumatic heart disease, in which leaflet fibrosis, thickening and commissural fusion predominate. These MV changes restrict systolic and diastolic leaflet mobility and result in mitral stenosis (MS) and / or MR [148].

\section{Treatment Strategies}

Acute rheumatic MR treatment is similar to MVP patients and MV repair the goal whenever possible. Treatment of later rheumatic heart disease stages and combined MS and MR oftentimes requires MV replacement [149].

\section{Future Directions}

Cardiovascular imaging advancements in MR quantification and LV function and structure assessment will be critical to refine the optimal time point of therapeutic MV intervention, which will no doubt further develop towards less invasive and transcatheter MV repair options. Ongoing genetic studies will lead to improved understanding of the mechanisms underlying and promoting primary MV disease. Such knowledge could allow to identify patients at risk without yet established MV disease and may open a therapeutic time window to medically prevent or limit degenerative / myxomatous leaflet remodeling. Mechanistic studies in secondary MV disease will likewise explore associated leaflet changes on a cellular and tissue level to identify therapies that maintain and promote leaflet function and 
thereby reduce adverse outcomes. Significant MR related to LV dysfunction might also conceivably be rescued and its development limited by future directed cell / gene therapies targeting the myocardium.

\section{Summary}

Normal anatomy and function of the LV, papillary muscles, chordae, mitral annulus and leaflets ensures effective leaflet coaptation and prevents leaflet tethering, prolapse and LVOT obstruction. Any temporal and spatial impairment of leaflet coaptation that exhausts leaflet redundancy may result in mitral regurgitation. Apical - annular leaflet tethering with restricted leaflet motion is characteristic for functional / ischemic MR; excessive leaflet and chordal motion and extensibility are characteristic for MVP (posterior leaflet), flail leaflets and rheumatic MR (anterior leaflet); SAM and elongated MV leaflets are typical for MR in HCM [77, 150]. A comprehensive understanding of MR and its mechanisms is essential for correct diagnosis and explains the rationale for optimal treatment [40].

\section{Acknowledgments}

Financial support:

This work is supported in part by grant 07CVD04 of the Leducq Foundation, Paris, France, for the Leducq Transatlantic MITRAL Network, and by National Institutes of Health grants K24 HL67434, R01 HL72265, and HL109506.

\section{References}

1. Levy MJ, Edwards JE. Anatomy of mitral insufficiency. Prog Cardiovasc Dis. 1962; 5:119-144. [PubMed: 14464797]

2. Levine RA, Schwammenthal E. Ischemic mitral regurgitation on the threshold of a solution: from paradoxes to unifying concepts. Circulation. 2005; 112(5):745-758. [PubMed: 16061756]

3. Otsuji Y, Handschumacher MD, Schwammenthal E, Jiang L, Song JK, Guerrero JL, Vlahakes GJ, Levine RA. Insights from three-dimensional echocardiography into the mechanism of functional mitral regurgitation: direct in vivo demonstration of altered leaflet tethering geometry. Circulation. 1997; 96(6):1999-2008. [PubMed: 9323092]

4. Chaput M, Handschumacher MD, Guerrero JL, Holmvang G, Dal-Bianco JP, Sullivan S, Vlahakes GJ, Hung J, Levine RA. Mitral leaflet adaptation to ventricular remodeling: prospective changes in a model of ischemic mitral regurgitation. Circulation. 2009; 120(11 Suppl):S99-S103. [PubMed: 19752393]

5. Nkomo VT, Gardin JM, Skelton TN, Gottdiener JS, Scott CG, Enriquez-Sarano M. Burden of valvular heart diseases: a population-based study. Lancet. 2006; 368(9540):1005-1011. [PubMed: 16980116]

6. Aikawa E, Whittaker P, Farber M, Mendelson K, Padera RF, Aikawa M, Schoen FJ. Human semilunar cardiac valve remodeling by activated cells from fetus to adult: implications for postnatal adaptation, pathology, and tissue engineering. Circulation. 2006; 113(10):1344-1352. [PubMed: 16534030]

7. Mautner SL, Klues HG, Mautner GC, Proschan MA, Roberts WC, Maron BJ. Comparison of mitral valve dimensions in adults with valvular aortic stenosis, pure aortic regurgitation and hypertrophic cardiomyopathy. The American journal of cardiology. 1993; 71(11):949-953. [PubMed: 8465787]

8. Chiechi MA, Lees WM, Thompson R. Functional anatomy of the normal mitral valve. J Thorac Surg. 1956; 32(3):378-398. [PubMed: 13358125]

9. Kim DH, Handschumacher MD, Levine RA, Choi YS, Kim YJ, Yun SC, Song JM, Kang DH, Song JK. In vivo measurement of mitral leaflet surface area and subvalvular geometry in patients with 
asymmetrical septal hypertrophy: insights into the mechanism of outflow tract obstruction. Circulation. 2010; 122(13):1298-1307. [PubMed: 20837895]

10. Chaput M, Handschumacher MD, Tournoux F, Hua L, Guerrero JL, Vlahakes GJ, Levine RA. Mitral leaflet adaptation to ventricular remodeling: occurrence and adequacy in patients with functional mitral regurgitation. Circulation. 2008; 118(8):845-852. [PubMed: 18678770]

11. Rusted IE, Scheifley CH, Edwards JE. Studies of the mitral valve. I. Anatomic features of the normal mitral valve and associated structures. Circulation. 1952; 6(6):825-831. [PubMed: 12998105]

12. Carpentier, A.; Guerinon, J.; Deloche, A.; Fabiani, JN.; Relland, M. THE MITRAL VALVE-A Pluridisciplinary Approach. Kalmanson, D., editor. Acton, MA: Publishing Sciences Group Inc.; 1976.

13. Levine RA, Handschumacher MD, Sanfilippo AJ, Hagege AA, Harrigan P, Marshall JE, Weyman AE. Three-dimensional echocardiographic reconstruction of the mitral valve, with implications for the diagnosis of mitral valve prolapse. Circulation. 1989; 80(3):589-598. [PubMed: 2766511]

14. Levine RA, Triulzi MO, Harrigan P, Weyman AE. The relationship of mitral annular shape to the diagnosis of mitral valve prolapse. Circulation. 1987; 75(4):756-767. [PubMed: 3829339]

15. Williams TH, Folan JC, Jew JY, Wang YF. Variations in atrioventricular valve innervation in four species of mammals. American Journal of Anatomy. 1990; 187(2):193-200. [PubMed: 2301279]

16. Swanson JC, Davis LR, Arata K, Briones EP, Bothe W, Itoh A, Ingels NB, Miller DC. Characterization of mitral valve anterior leaflet perfusion patterns. Journal of Heart Valve Disease. 2009; 18(5):488-495. [PubMed: 20099688]

17. Puff, A. Ischemic Mitral Incompetence. Vetter, HO.; Hetzer, R.; Schmutzler, H., editors. New York: Springer; 1991.

18. Veronesi F, Corsi C, Sugeng L, Mor-Avi V, Caiani EG, Weinert L, Lamberti C, Lang RM. A study of functional anatomy of aortic-mitral valve coupling using 3D matrix transesophageal $\mathrm{e}$ chocardiography. Circ Cardiovasc Imaging. 2009; 2(1):24-31. [PubMed: 19808561]

19. Alkadhi H, Desbiolles L, Stolzmann P, Leschka S, Scheffel H, Plass A, Schertler T, Trindade PT, Genoni M, Cattin P, Marincek B, Frauenfelder T. Mitral annular shape, size, and motion in normals and in patients with cardiomyopathy: evaluation with computed tomography. Investigative radiology. 2009; 44(4):218-225. [PubMed: 19212270]

20. Ormiston JA, Shah PM, Tei C, Wong M. Size and motion of the mitral valve annulus in man. I. A two-dimensional echocardiographic method and findings in normal subjects. Circulation. 1981; 64(1):113-120. [PubMed: 7237707]

21. Flachskampf FA, Chandra S, Gaddipatti A, Levine RA, Weyman AE, Ameling W, Hanrath P, Thomas JD. Analysis of shape and motion of the mitral annulus in subjects with and without cardiomyopathy by echocardiographic 3-dimensional reconstruction. J Am Soc Echocardiogr. 2000; 13(4):277-287. [PubMed: 10756245]

22. Komoda T, Hetzer R, Oellinger J, Sinlawski H, Hofmeister J, Hubler M, Felix R, Uyama C, Maeta H. Mitral annular flexibility. Journal of Cardiac Surgery. 1997; 12(2):102-109. [PubMed: 9271730]

23. Komoda T, Hetzer R, Uyama C, Siniawski H, Maeta H, Rosendahl UP, Ozaki K. Mitral annular function assessed by 3D imaging for mitral valve surgery. Journal of Heart Valve Disease. 1994; 3(5):483-490. [PubMed: 8000581]

24. Daimon M, Saracino G, Fukuda S, Koyama Y, Kwan J, Song JM, Agler DA, Gillinov AM, Thomas JD, Shiota T. Dynamic change of mitral annular geometry and motion in ischemic mitral regurgitation assessed by a computerized 3D echo method. Echocardiography (Mount Kisco, N.Y.). 2010; 27(9):1069-1077.

25. Salgo IS, Gorman JH 3rd, Gorman RC, Jackson BM, Bowen FW, Plappert T, St John Sutton MG, Edmunds LH Jr. Effect of annular shape on leaflet curvature in reducing mitral leaflet stress. Circulation. 2002; 106(6):711-717. [PubMed: 12163432]

26. Kunzelman KS, Reimink MS, Cochran RP. Annular dilatation increases stress in the mitral valve and delays coaptation: a finite element computer model. Cardiovascular surgery (London, England). 1997; 5(4):427-434. 
27. Jimenez JH, Liou SW, Padala M, He Z, Sacks M, Gorman RC, Gorman JH 3rd, Yoganathan AP. A saddle-shaped annulus reduces systolic strain on the central region of the mitral valve anterior leaflet. The Journal of thoracic and cardiovascular surgery. 2007; 134(6):1562-1568. [PubMed: 18023684]

28. Padala M, Hutchison RA, Croft LR, Jimenez JH, Gorman RC, Gorman JH 3rd, Sacks MS, Yoganathan AP. Saddle shape of the mitral annulus reduces systolic strains on the P2 segment of the posterior mitral leaflet. The Annals of thoracic surgery. 2009; 88(5):1499-1504. [PubMed: 19853100]

29. Jensen MO, Jensen H, Levine RA, Yoganathan AP, Andersen NT, Nygaard H, Hasenkam JM, Nielsen SL. Saddle-shaped mitral valve annuloplasty rings improve leaflet coaptation geometry. The Journal of thoracic and cardiovascular surgery. 2011; 142(3):697-703. [PubMed: 21329946]

30. Jensen MO, Hagege AA, Otsuji Y, Levine RA. The unsaddled annulus: biomechanical culprit in mitral valve prolapse? Circulation. 2013; 127(7):766-768. [PubMed: 23429895]

31. Lam JH, Ranganathan N, Wigle ED, Silver MD. Morphology of the human mitral valve. I. Chordae tendineae: a new classification. Circulation. 1970; 41(3):449-458. [PubMed: 5415982]

32. Millington-Sanders C, Meir A, Lawrence L, Stolinski C. Structure of chordae tendineae in the left ventricle of the human heart. Journal of anatomy. 1998; 192(Pt 4):573-581. [PubMed: 9723984]

33. Liao J, Vesely I. A structural basis for the size-related mechanical properties of mitral valve chordae tendineae. J Biomech. 2003; 36(8):1125-1133. [PubMed: 12831738]

34. Degandt AA, Weber PA, Saber HA, Duran CM. Mitral valve basal chordae: comparative anatomy and terminology. The Annals of Thoracic Surgery. 2007; 84(4):1250-1255. [PubMed: 17888977]

35. Oosthoek PW, Wenink AC, Wisse LJ, Gittenberger-de Groot AC. Development of the papillary muscles of the mitral valve: morphogenetic background of parachute-like asymmetric mitral valves and other mitral valve anomalies. The Journal of thoracic and cardiovascular surgery. 1998; 116(1):36-46. [PubMed: 9671895]

36. Victor S, Nayak VM. Variations in the papillary muscles of the normal mitral valve and their surgical relevance. Journal of Cardiac Surgery. 1995; 10(5):597-607. [PubMed: 7488788]

37. Komeda M, Glasson JR, Bolger AF, Daughters GT 2nd, Ingels NB Jr, Miller DC. Papillary muscle-left ventricular wall "complex". The Journal of thoracic and cardiovascular surgery. 1997; 113(2):292-300. discussion 300-1. [PubMed: 9040623]

38. Joudinaud TM, Kegel CL, Flecher EM, Weber PA, Lansac E, Hvass U, Duran CM. The papillary muscles as shock absorbers of the mitral valve complex. An experimental study. Eur J Cardiothorac Surg. 2007; 32(1):96-101. [PubMed: 17512209]

39. Gorman JH 3rd, Gupta KB, Streicher JT, Gorman RC, Jackson BM, Ratcliffe MB, Bogen DK, Edmunds LH Jr. Dynamic three-dimensional imaging of the mitral valve and left ventricle by rapid sonomicrometry array localization. The Journal of thoracic and cardiovascular surgery. 1996; 112(3):712-726. [PubMed: 8800160]

40. Carpentier A. Cardiac valve surgery--the "French correction". The Journal of thoracic and cardiovascular surgery. 1983; 86(3):323-337. [PubMed: 6887954]

41. Carpentier A, Chauvaud S, Fabiani JN, Deloche A, Relland J, Lessana A, D'Allaines C, Blondeau P, Piwnica A, Dubost C. Reconstructive surgery of mitral valve incompetence: ten-year appraisal. The Journal of thoracic and cardiovascular surgery. 1980; 79(3):338-348. [PubMed: 7354634]

42. Dal-Bianco JP, Aikawa E, Bischoff J, Guerrero JL, Handschumacher MD, Sullivan S, Johnson B, Titus JS, Iwamoto Y, Wylie-Sears J, Levine RA, Carpentier A. Active adaptation of the tethered mitral valve: insights into a compensatory mechanism for functional mitral regurgitation. Circulation. 2009; 120(4):334-342. [PubMed: 19597052]

43. Watanabe N, Ogasawara Y, Yamaura Y, Wada N, Kawamoto T, Toyota E, Akasaka T, Yoshida K. Mitral annulus flattens in ischemic mitral regurgitation: geometric differences between inferior and anterior myocardial infarction: a real-time 3-dimensional echocardiographic study. Circulation. 2005; 112(9 Suppl):I458-I462. [PubMed: 16159863]

44. Reimink MS, Kunzelman KS, Verrier ED, Cochran RP. The effect of anterior chordal replacement on mitral valve function and stresses. A finite element study. ASAIO journal (American Society for Artificial Internal Organs: 1992). 1995; 41(3):M754-M762. [PubMed: 8573908] 
45. Lee AP, Hsiung MC, Salgo IS, Fang F, Xie JM, Zhang YC, Lin QS, Looi JL, Wan S, Wong RH, Underwood MJ, Sun JP, Yin WH, Wei J, Tsai SK, Yu CM. Quantitative analysis of mitral valve morphology in mitral valve prolapse with real-time 3-dimensional echocardiography: importance of annular saddle shape in the pathogenesis of mitral regurgitation. Circulation. 2013; 127(7):832841. [PubMed: 23266859]

46. Grewal J, Suri R, Mankad S, Tanaka A, Mahoney DW, Schaff HV, Miller FA, Enriquez-Sarano M. Mitral annular dynamics in myxomatous valve disease: new insights with real-time 3-dimensional echocardiography. Circulation. 2010; 121(12):1423-1431. [PubMed: 20231533]

47. Gertz ZM, Raina A, Saghy L, Zado ES, Callans DJ, Marchlinski FE, Keane MG, Silvestry FE. Evidence of atrial functional mitral regurgitation due to atrial fibrillation: reversal with arrhythmia control. Journal of the American College of Cardiology. 2011; 58(14):1474-1481. [PubMed: 21939832]

48. Hoit BD. Atrial functional mitral regurgitation: the left atrium gets its due respect. Journal of the American College of Cardiology. 2011; 58(14):1482-1484. [PubMed: 21939833]

49. Obadia JF, Casali C, Chassignolle JF, Janier M. Mitral subvalvular apparatus: different functions of primary and secondary chordae. Circulation. 1997; 96(9):3124-3128. [PubMed: 9386184]

50. Thompson CR, Buller CE, Sleeper LA, Antonelli TA, Webb JG, Jaber WA, Abel JG, Hochman JS. Cardiogenic shock due to acute severe mitral regurgitation complicating acute myocardial infarction: a report from the SHOCK Trial Registry. SHould we use emergently revascularize Occluded Coronaries in cardiogenic shocK? J Am Coll Cardiol. 2000; 36 Suppl A(3):1104-1109. [PubMed: 10985712]

51. Feldman T, Kar S, Rinaldi M, Fail P, Hermiller J, Smalling R, Whitlow PL, Gray W, Low R, Herrmann HC, Lim S, Foster E, Glower D. Percutaneous mitral repair with the MitraClip system: safety and midterm durability in the initial EVEREST (Endovascular Valve Edge-to-Edge REpair Study) cohort. Journal of the American College of Cardiology. 2009; 54(8):686-694. [PubMed: 19679246]

52. Freed LA, Levy D, Levine RA, Larson MG, Evans JC, Fuller DL, Lehman B, Benjamin EJ. Prevalence and clinical outcome of mitral-valve prolapse. The New England journal of medicine. 1999; 341(1):1-7. [PubMed: 10387935]

53. Levine RA, Stathogiannis E, Newell JB, Harrigan P, Weyman AE. Reconsideration of echocardiographic standards for mitral valve prolapse: lack of association between leaflet displacement isolated to the apical four chamber view and independent echocardiographic evidence of abnormality. Journal of the American College of Cardiology. 1988; 11(5):1010-1019. [PubMed: 3281989]

54. Sanfilippo AJ, Harrigan P, Popovic AD, Weyman AE, Levine RA. Papillary muscle traction in mitral valve prolapse: quantitation by two-dimensional echocardiography. Journal of the American College of Cardiology. 1992; 19(3):564-571. [PubMed: 1538011]

55. Gornick CC, Tobler HG, Pritzker MC, Tuna IC, Almquist A, Benditt DG. Electrophysiologic effects of papillary muscle traction in the intact heart. Circulation. 1986; 73(5):1013-1021. [PubMed: 3698223]

56. Enriquez-Sarano M, Basmadjian AJ, Rossi A, Bailey KR, Seward JB, Tajik AJ. Progression of mitral regurgitation: a prospective Doppler echocardiographic study. J Am Coll Cardiol. 1999; 34(4):1137-1144. [PubMed: 10520803]

57. Rabkin E, Aikawa M, Stone JR, Fukumoto Y, Libby P, Schoen FJ. Activated interstitial myofibroblasts express catabolic enzymes and mediate matrix remodeling in myxomatous heart valves. Circulation. 2001; 104(21):2525-2532. [PubMed: 11714645]

58. Fornes P, Heudes D, Fuzellier JF, Tixier D, Bruneval P, Carpentier A. Correlation between clinical and histologic patterns of degenerative mitral valve insufficiency: a histomorphometric study of 130 excised segments. Cardiovasc Pathol. 1999; 8(2):81-92. [PubMed: 10724505]

59. Ng CM, Cheng A, Myers LA, Martinez-Murillo F, Jie C, Bedja D, Gabrielson KL, Hausladen JM, Mecham RP, Judge DP, Dietz HC. TGF-beta-dependent pathogenesis of mitral valve prolapse in a mouse model of Marfan syndrome. J Clin Invest. 2004; 114(11):1586-1592. [PubMed: 15546004]

60. McKusick, VA. Heritable Disorders of Connective Tissue. Fourth ed.. C. V. Mosby Company; 1972. 
61. Loeys BL, Chen J, Neptune ER, Judge DP, Podowski M, Holm T, Meyers J, Leitch CC, Katsanis N, Sharifi N, Xu FL, Myers LA, Spevak PJ, Cameron DE, De Backer J, Hellemans J, Chen Y, Davis EC, Webb CL, Kress W, Coucke P, Rifkin DB, De Paepe AM, Dietz HC. A syndrome of altered cardiovascular, craniofacial, neurocognitive and skeletal development caused by mutations in TGFBR1 or TGFBR2. Nat Genet. 2005; 37(3):275-281. [PubMed: 15731757]

62. Nesta F, Leyne M, Yosefy C, Simpson C, Dai D, Marshall JE, Hung J, Slaugenhaupt SA, Levine RA. New locus for autosomal dominant mitral valve prolapse on chromosome 13: clinical insights from genetic studies. Circulation. 2005; 112(13):2022-2030. [PubMed: 16172273]

63. Freed LA, Acierno JS Jr, Dai D, Leyne M, Marshall JE, Nesta F, Levine RA, Slaugenhaupt SA. A locus for autosomal dominant mitral valve prolapse on chromosome 11p15.4. Am J Hum Genet. 2003; 72(6):1551-1559. [PubMed: 12707861]

64. Disse S, Abergel E, Berrebi A, Houot AM, Le Heuzey JY, Diebold B, Guize L, Carpentier A, Corvol P, Jeunemaitre X. Mapping of a first locus for autosomal dominant myxomatous mitralvalve prolapse to chromosome 16p11.2-p12.1. Am J Hum Genet. 1999; 65(5):1242-1251. [PubMed: 10521289]

65. Kyndt F, Gueffet JP, Probst V, Jaafar P, Legendre A, Le Bouffant F, Toquet C, Roy E, McGregor L, Lynch SA, Newbury-Ecob R, Tran V, Young I, Trochu JN, Le Marec H, Schott JJ. Mutations in the gene encoding filamin A as a cause for familial cardiac valvular dystrophy. Circulation. 2007; 115(1):40-49. [PubMed: 17190868]

66. Kyndt F, Schott J-J, Trochu J-N, Baranger F, Herbert O, Scott V, Fressinaud E, David A, Moisan J-P, Bouhour J-B, Le Marec H, Bénichou B. Mapping of X-Linked Myxomatous Valvular Dystrophy to Chromosome Xq28. The American Journal of Human Genetics. 1998; 62(3):627632.

67. Nakamura F, Stossel TP, Hartwig JH. The filamins: Organizers of cell structure and function. Cell Adh Migr. 2011; 5(2):160-169. [PubMed: 21169733]

68. Ling LH, Enriquez-Sarano M, Seward JB, Tajik AJ, Schaff HV, Bailey KR, Frye RL. Clinical outcome of mitral regurgitation due to flail leaflet. N Engl J Med. 1996; 335(19):1417-1423. [PubMed: 8875918]

69. Enriquez-Sarano M, Akins CW, Vahanian A. Mitral regurgitation. Lancet. 2009; 373(9672):13821394. [PubMed: 19356795]

70. Bonow RO. Chronic mitral regurgitation and aortic regurgitation: have indications for surgery changed? J Am Coll Cardiol. 2013; 61(7):693-701. [PubMed: 23265342]

71. Fucci C, Sandrelli L, Pardini A, Torracca L, Ferrari M, Alfieri O. Improved results with mitral valve repair using new surgical techniques. Eur J Cardiothorac Surg. 1995; 9(11):621-626. discuss 626-7. [PubMed: 8751250]

72. Nishimura RA, Otto CM, Bonow RO, Carabello BA, Erwin JP 3rd, Guyton RA, O'Gara PT, Ruiz CE, Skubas NJ, Sorajja P, Sundt TM 3rd, Thomas JD. 2014 AHA/ACC Guideline for the Management of Patients With Valvular Heart Disease: A Report of the American College of Cardiology/American Heart Association Task Force on Practice Guidelines. Circulation. 2014; 129(23):e521-e643. [PubMed: 24589853]

73. Enriquez-Sarano M, Sundt TM 3rd. Early surgery is recommended for mitral regurgitation. Circulation. 2010; 121(6):804-811. discussion 812. [PubMed: 20159841]

74. Enriquez-Sarano M, Schaff HV, Orszulak TA, Tajik AJ, Bailey KR, Frye RL. Valve repair improves the outcome of surgery for mitral regurgitation. A multivariate analysis. Circulation. 1995; 91(4):1022-1028. [PubMed: 7850937]

75. Kang DH, Park SJ, Sun BJ, Cho EJ, Kim DH, Yun SC, Song JM, Park SW, Chung CH, Song JK, Lee JW, Park PW. Early Surgery Versus Conventional Treatment for Asymptomatic S evere Mitral Regurgitation: A Propensity Analysis. J Am Coll Cardiol. 2014

76. Bizzarri F, Tudisco A, Ricci M, Rose D, Frati G. Different ways to repair the mitral valve with artificial chordae: a systematic review. J Cardiothorac Surg. 2010; 5:22. [PubMed: 20377866]

77. Maslow AD, Regan MM, Haering JM, Johnson RG, Levine RA. Echocardiographic predictors of left ventricular outflow tract obstruction and systolic anterior motion of the mitral valve after mitral valve reconstruction for myxomatous valve disease. J Am Coll Cardiol. 1999; 34(7):20962104. [PubMed: 10588230] 
78. Varghese R, Itagaki S, Anyanwu AC, Trigo P, Fischer G, Adams DH. Predicting systolic anterior motion after mitral valve reconstruction: using intraoperative transoesophageal echocardiography to identify those at greatest risk. Eur J Cardiothorac Surg. 2014; 45(1):132-137. discussion 137-8. [PubMed: 23657548]

79. Kaul S, Spotnitz WD, Glasheen WP, Touchstone DA. Mechanism of ischemic mitral regurgitation. An experimental evaluation. Circulation. 1991; 84(5):2167-2180. [PubMed: 1934385]

80. Kono T, Sabbah HN, Rosman H, Alam M, Jafri S, Goldstein S. Left ventricular shape is the primary determinant of functional mitral regurgitation in heart failure. J Am Coll Cardiol. 1992; 20(7):1594-1598. [PubMed: 1452934]

81. Sabbah HN, Kono T, Stein PD, Mancini GB, Goldstein S. Left ventricular shape changes during the course of evolving heart failure. Am J Physiol. 1992; 263(1 Pt 2):H266-H270. [PubMed: 1636764]

82. Sabbah HN, Rosman H, Kono T, Alam M, Khaja F, Goldstein S. On the mechanism of functional mitral regurgitation. Am J Cardiol. 1993; 72(14):1074-1076. [PubMed: 8213590]

83. Yiu SF, Enriquez-Sarano M, Tribouilloy C, Seward JB, Tajik AJ. Determinants of the degree of functional mitral regurgitation in patients with systolic left ventricular dysfunction: A quantitative clinical study. Circulation. 2000; 102(12):1400-1406. [PubMed: 10993859]

84. Otsuji Y, Handschumacher MD, Liel-Cohen N, Tanabe H, Jiang L, Schwammenthal E, Guerrero JL, Nicholls LA, Vlahakes GJ, Levine RA. Mechanism of ischemic mitral regurgitation with segmental left ventricular dysfunction: three-dimensional echocardiographic studies in models of acute and chronic progressive regurgitation. J Am Coll Cardiol. 2001; 37(2):641-648. [PubMed: 11216991]

85. He S, Fontaine AA, Schwammenthal E, Yoganathan AP, Levine RA. Integrated mechanism for functional mitral regurgitation: leaflet restriction versus coapting force: in vitro studies. Circulation. 1997; 96(6):1826-1834. [PubMed: 9323068]

86. Gorman RC, McCaughan JS, Ratcliffe MB, Gupta KB, Streicher JT, Ferrari VA, St John-Sutton MG, Bogen DK, Edmunds LH Jr. Pathogenesis of acute ischemic mitral regurgitation in three dimensions. J Thorac Cardiovasc Surg. 1995; 109(4):684-693. [PubMed: 7715215]

87. Liel-Cohen N, Guerrero JL, Otsuji Y, Handschumacher MD, Rudski LG, Hunziker PR, Tanabe H, Scherrer-Crosbie M, Sullivan S, Levine RA. Design of a new surgical approach for ventricular remodeling to relieve ischemic mitral regurgitation: insights from 3-dimensional echocardiography. Circulation. 2000; 101(23):2756-2763. [PubMed: 10851215]

88. Llaneras MR, Nance ML, Streicher JT, Lima JA, Savino JS, Bogen DK, Deac RF, Ratcliffe MB, Edmunds LH Jr. Large animal model of ischemic mitral regurgitation. Ann Thorac Surg. 1994; 57(2):432-439. [PubMed: 8311608]

89. Perloff JK, Roberts WC. The mitral apparatus. Functional anatomy of mitral regurgitation. Circulation. 1972; 46(2):227-239. [PubMed: 5046018]

90. Silverman ME, Hurst JW. The mitral complex. Interaction of the anatomy, physiology, and pathology of the mitral annulus, mitral valve leaflets, chordae tendineae, and papillary muscles. Am Heart J. 1968; 76(3):399-418. [PubMed: 4952735]

91. Godley RW, Wann LS, Rogers EW, Feigenbaum H, Weyman AE. Incomplete mitral leaflet closure in patients with papillary muscle dysfunction. Circulation. 1981; 63(3):565-571. [PubMed: 7460242]

92. Ogawa S, Hubbard FE, Mardelli TJ, Dreifus LS. Cross-sectional echocardiographic spectrum of papillary muscle dysfunction. Am Heart J. 1979; 97(3):312-321. [PubMed: 420070]

93. Otsuji Y, Gilon D, Jiang L, He S, Leavitt M, Roy MJ, Birmingham MJ, Levine RA. Restricted diastolic opening of the mitral leaflets in patients with left ventricular dysfunction: evidence for increased valve tethering. J Am Coll Cardiol. 1998; 32(2):398-404. [PubMed: 9708467]

94. Gillam LD. Is it time to update the definition of functional mitral regurgitation?: structural changes in the mitral leaflets with left ventricular dysfunction. Circulation. 2008; 118(8):797-799. [PubMed: 18711022]

95. Dal-Bianco JP, Aikawa E, Bischoff J, Handschumacher MD, Guerrero JL, Szymanski C, Chaput M, Sullivan S, Johnson B, Titus JS, Iwamoto Y, Wylie-Sears J, Carpentier A, Levine RA. Mitral Valve Adaptation is Augmented in Myocardial Infarction: A Three-Dimensional 
Echocardiographic-Histopathologic Follow-Up Study. Journal of the American Society of Echocardiography. 2009; 22(5):544.

96. Grande-Allen KJ, Barber JE, Klatka KM, Houghtaling PL, Vesely I, Moravec CS, McCarthy PM. Mitral valve stiffening in end-stage heart failure: evidence of an organic contribution to functional mitral regurgitation. J Thorac Cardiovasc Surg. 2005; 130(3):783-790. [PubMed: 16153929]

97. Grande-Allen KJ, Borowski AG, Troughton RW, Houghtaling PL, Dipaola NR, Moravec CS, Vesely I, Griffin BP. Apparently normal mitral valves in patients with heart failure demonstrate biochemical and structural derangements: an extracellular matrix and echocardiographic study. $\mathrm{J}$ Am Coll Cardiol. 2005; 45(1):54-61. [PubMed: 15629373]

98. Beaudoin J, Handschumacher MD, Zeng X, Hung J, Morris EL, Levine RA, Schwammenthal E. Mitral valve enlargement in chronic aortic regurgitation as a compensatory mechanism to prevent functional mitral regurgitation in the dilated left ventricle. Journal of the American College of Cardiology. 2013; 61(17):1809-1816. [PubMed: 23500248]

99. Beaudoin J, Thai WE, Wai B, Handschumacher MD, Levine RA, Truong QA. Assessment of mitral valve adaptation with gated cardiac computed tomography: validation with threedimensional echocardiography and mechanistic insight to functional mitral regurgitation. Circ Cardiovasc Imaging. 2013; 6(5):784-789. [PubMed: 23873402]

100. Balachandran K, Alford PW, Wylie-Sears J, Goss JA, Grosberg A, Bischoff J, Aikawa E, Levine RA, Parker KK. Cyclic strain induces dual-mode endothelial-mesenchymal transformation of the cardiac valve. Proc Natl Acad Sci U S A. 2011; 108(50):19943-19948. [PubMed: 22123981]

101. Beaudoin JD-BJ, Aikawa E, Biscoff J, Guerrero L, Sullivan S, Wylie-Sears J, Aaron J, Levine RA. Mitral leaflet changes following myocardial infarction: evidence for maladaptive remodeling favoring ischemic mitral regurgitation. J Am Coll Cardiol. 2012; 59(13s1):E2136-E2136.

102. Stephens EH, Timek TA, Daughters GT, Kuo JJ, Patton AM, Baggett LS, Ingels NB, Miller DC, Grande-Allen KJ. Significant changes in mitral valve leaflet matrix composition and turnover with tachycardia-induced cardiomyopathy. Circulation. 2009; 120(11 Suppl):S112-S119. [PubMed: 19752355]

103. Di Donato M, Frigiola A, Menicanti L, Boghdabi A, Badia T, Neagu A, Montericcio V, Ranucci M. Moderate ischemic mitral regurgitation and coronary artery bypass surgery: effect of mitral repair on clinical outcome. J Heart Valve Dis. 2003; 12(3):272-279. [PubMed: 12803324]

104. Trichon BH, Glower DD, Shaw LK, Cabell CH, Anstrom KJ, Felker GM, O'Connor CM. Survival after coronary revascularization, with and without mitral valve surgery, in patients with ischemic mitral regurgitation. Circulation. 2003; 108(Suppl 1):II103-II110. [PubMed: 12970217]

105. Tenenbaum A, Leor J, Motro M, Hod H, Kaplinsky E, Rabinowitz B, Boyko V, Vered Z. Improved posterobasal segment function after thrombolysis is associated with decreased incidence of significant mitral regurgitation in a first inferior myocardial infarction. Journal of the American College of Cardiology. 1995; 25(7):1558-1563. [PubMed: 7759707]

106. Kanzaki H, Bazaz R, Schwartzman D, Dohi K, Sade LE, Gorcsan J 3rd. A mechanism for immediate reduction in mitral regurgitation after cardiac resynchronization therapy: insights from mechanical activation strain mapping. Journal of the American College of Cardiology. 2004; 44(8):1619-1625. [PubMed: 15489094]

107. Solis J, McCarty D, Levine RA, Handschumacher MD, Fernandez-Friera L, Chen-Tournoux A, Mont L, Vidal B, Singh JP, Brugada J, Picard MH, Sitges M, Hung J. Mechanism of decrease in mitral regurgitation after cardiac resynchronization therapy: optimization of the force-balance relationship. Circulation. Cardiovascular imaging. 2009; 2(6):444-450. [PubMed: 19920042]

108. Beeri R, Guerrero JL, Supple G, Sullivan S, Levine RA, Hajjar RJ. New efficient catheter-based system for myocardial gene delivery. Circulation. 2002; 106(14):1756-1759. [PubMed: 12356625]

109. Messas E, Bel A, Morichetti MC, Carrion C, Handschumacher MD, Peyrard S, Vilquin JT, Desnos M, Bruneval P, Carpentier A, Menasche P, Levine RA, Hagege AA. Autologous myoblast transplantation for chronic ischemic mitral regurgitation. J Am Coll Cardiol. 2006; 47(10):2086-2093. [PubMed: 16697329]

110. Cittadini A, Monti MG, Iaccarino G, Di Rella F, Tsichlis PN, Di Gianni A, Stromer H, Sorriento D, Peschle C, Trimarco B, Sacca L, Condorelli G. Adenoviral gene transfer of Akt enhances 
myocardial contractility and intracellular calcium handling. Gene Ther. 2006; 13(1):8-19. [PubMed: 16094411]

111. Hagege AA, Marolleau JP, Vilquin JT, Alheritiere A, Peyrard S, Duboc D, Abergel E, Messas E, Mousseaux E, Schwartz K, Desnos M, Menasche P. Skeletal myoblast transplantation in ischemic heart failure: long-term follow-up of the first phase I cohort of patients. Circulation. 2006; 114(1 Suppl):I108-I113. [PubMed: 16820558]

112. Acker MA, Parides MK, Perrault LP, Moskowitz AJ, Gelijns AC, Voisine P, Smith PK, Hung JW, Blackstone EH, Puskas JD, Argenziano M, Gammie JS, Mack M, Ascheim DD, Bagiella E, Moquete EG, Ferguson TB, Horvath KA, Geller NL, Miller MA, Woo YJ, D'Alessandro DA, Ailawadi G, Dagenais F, Gardner TJ, O'Gara PT, Michler RE, Kron IL. Mitral-valve repair versus replacement for severe ischemic mitral regurgitation. N Engl J Med. 2014; 370(1):23-32. [PubMed: 24245543]

113. Hung J, Chaput M, Guerrero JL, Handschumacher MD, Papakostas L, Sullivan S, Solis J, Levine RA. Persistent reduction of ischemic mitral regurgitation by papillary muscle repositioning: structural stabilization of the papillary muscle-ventricular wall complex. Circulation. 2007; 116(11 Suppl):I259-I263. [PubMed: 17846314]

114. Hung J, Guerrero JL, Handschumacher MD, Supple G, Sullivan S, Levine RA. Reverse ventricular remodeling reduces ischemic mitral regurgitation: echo-guided device application in the beating heart. Circulation. 2002; 106(20):2594-2600. [PubMed: 12427657]

115. Solis J, Levine RA, Johnson B, Guerrero JL, Handschumacher MD, Sullivan S, Lam K, Berlin J, Braithwaite GJ, Muratoglu OK, Vlahakes GJ, Hung J. Polymer injection therapy to reverse remodel the papillary muscles: efficacy in reducing mitral regurgitation in a chronic ischemic model. Circ Cardiovasc Interv. 2010; 3(5):499-505. [PubMed: 20736444]

116. Matsui Y, Suto Y, Shimura S, Fukada Y, Naito Y, Yasuda K, Sasaki S. Impact of papillary muscles approximation on the adequacy of mitral coaptation in functional mitral regurgitation due to dilated cardiomyopathy. Annals of thoracic and cardiovascular surgery : official journal of the Association of Thoracic and Cardiovascular Surgeons of Asia. 2005; 11(3):164-171.

117. Messas E, Bel A, Szymanski C, Cohen I, Touchot B, Handschumacher MD, Desnos M, Carpentier A, Menasche P, Hagege AA, Levine RA. Relief of Mitral Leaflet Tethering Following Chronic Myocardial Infarction by Chordal Cutting Diminishes Left Ventricular Remodeling. Circ Cardiovasc Imaging. 2010 Sep 8. 2010 [Epub ahead of print].

118. Messas E, Guerrero JL, Handschumacher MD, Conrad C, Chow CM, Sullivan S, Yoganathan AP, Levine RA. Chordal cutting: a new therapeutic approach for ischemic mitral regurgitation. Circulation. 2001; 104(16):1958-1963. [PubMed: 11602501]

119. Messas E, Pouzet B, Touchot B, Guerrero JL, Vlahakes GJ, Desnos M, Menasche P, Hagege A, Levine RA. Efficacy of chordal cutting to relieve chronic persistent ischemic mitral regurgitation. Circulation. 2003; 108(Suppl 1):II111-II115. [PubMed: 12970218]

120. Messas E, Yosefy C, Chaput M, Guerrero JL, Sullivan S, Menasche P, Carpentier A, Desnos M, Hagege AA, Vlahakes GJ, Levine RA. Chordal cutting does not adversely affect left ventricle contractile function. Circulation. 2006; 114(1 Suppl):I524-I528. [PubMed: 16820631]

121. Hung J, Papakostas L, Tahta SA, Hardy BG, Bollen BA, Duran CM, Levine RA. Mechanism of recurrent ischemic mitral regurgitation after annuloplasty: continued $\mathrm{LV}$ remodeling as a moving target. Circulation. 2004; 110 Suppl 1(11):II85-II90. [PubMed: 15364844]

122. Kuwahara E, Otsuji Y, Iguro Y, Ueno T, Zhu F, Mizukami N, Kubota K, Nakashiki K, Yuasa T, Yu B, Uemura T, Takasaki K, Miyata M, Hamasaki S, Kisanuki A, Levine RA, Sakata R, Tei C. Mechanism of recurrent/persistent ischemic/functional mitral regurgitation in the chronic phase after surgical annuloplasty: importance of augmented posterior leaflet tethering. Circulation. 2006; 114(1 Suppl):I529-I534. [PubMed: 16820632]

123. Liel-Cohen N, Otsuji Y, Vlahakes G, Akins C, Levine R. Functional Ischemic Mitral Regurgitation Can Persist Despite Ring Annuloplasty: Mechanistic Insights. Circulation. 1997; 96:I-540.

124. McGee EC, Gillinov AM, Blackstone EH, Rajeswaran J, Cohen G, Najam F, Shiota T, Sabik JF, Lytle BW, McCarthy PM, Cosgrove DM. Recurrent mitral regurgitation after annuloplasty for functional ischemic mitral regurgitation. The Journal of thoracic and cardiovascular surgery. 2004; 128(6):916-924. [PubMed: 15573077] 
125. Borger MA, Murphy PM, Alam A, Fazel S, Maganti M, Armstrong S, Rao V, David TE. Initial results of the chordal-cutting operation for ischemic mitral regurgitation. The Journal of thoracic and cardiovascular surgery. 2007; 133(6):1483-1492. [PubMed: 17532944]

126. Watkins H, Ashrafian H, Redwood C. Inherited cardiomyopathies. N Engl J Med. 2011; 364(17): 1643-1656. [PubMed: 21524215]

127. Harrigan CJ, Appelbaum E, Maron BJ, Buros JL, Gibson CM, Lesser JR, Udelson JE, Manning WJ, Maron MS. Significance of papillary muscle abnormalities identified by cardiovascular magnetic resonance in hypertrophic cardiomyopathy. The American Journal of Cardiology. 2008; 101(5):668-673. [PubMed: 18308018]

128. Hwang HJ, Choi EY, Kwan J, Kim SA, Shim CY, Ha JW, Rim SJ, Chung N, Kim SS. Dynamic change of mitral apparatus as potential cause of left ventricular outflow tract obstruction in hypertrophic ca rdiomyopathy. Eur J Echocardiogr. 2011; 12(1):19-25. [PubMed: 20693545]

129. Jiang L, Levine RA, King ME, Weyman AE. An integrated mechanism for systolic anterior motion of the mitral valve in hypertrophic cardiomyopathy based on echocardiographic observations. Am Heart J. 1987; 113(3):633-644. [PubMed: 3825854]

130. Klues HG, Roberts WC, Maron BJ. Morphological determinants of echocardiographic patterns of mitral valve systolic anterior motion in obstructive hypertrophic cardiomyopathy. Circulation. 1993; 87(5):1570-1579. [PubMed: 8491013]

131. Levine RA, Vlahakes GJ, Lefebvre X, Guerrero JL, Cape EG, Yoganathan AP, Weyman AE. Papillary muscle displacement causes systolic anterior motion of the mitral valve. Experimental validation and insights into the mechanism of subaortic obstruction. Circulation. 1995; 91(4): 1189-1195. [PubMed: 7850958]

132. Sherrid MV, Chu CK, Delia E, Mogtader A, Dwyer EM Jr. An echocardiographic study of the fluid mechanics of obstruction in hypertrophic cardiomyopathy. Journal of the American College of Cardiology. 1993; 22(3):816-825. [PubMed: 8354817]

133. Sherrid MV, Gunsburg DZ, Moldenhauer S, Pearle G. Systolic anterior motion begins at low left ventricular outflow tract velocity in obstructive hypertrophic cardiomyopathy. Journal of the American College of Cardiology. 2000; 36(4):1344-1354. [PubMed: 11028493]

134. Maron BJ, Gottdiener JS, Roberts WC, Henry WL, Savage DD, Epstein SE. Left ventricular outflow tract obstruction due to systolic anterior motion of the anterior mitral leaflet in patients with concentric left ventricular hypertrophy. Circulation. 1978; 57(3):527-533. [PubMed: 564246]

135. Maron BJ, Epstein SE. Hypertrophic cardiomyopathy. Recent observations regarding the specificity of three hallmarks of the disease: asymmetric septal hypertrophy, septal disorganization and systolic anterior motion of the anterior mitral leaflet. The American Journal of Cardiology. 1980; 45(1):141-154. [PubMed: 6985764]

136. Hagege AA, Bruneval P, Levine RA, Desnos M, Neamatalla H, Judge DP. The mitral valve in hypertrophic cardiomyopathy: old versus new concepts. Journal of cardiovascular translational research. 2011; 4(6):757-766. [PubMed: 21909825]

137. He S, Hopmeyer J, Lefebvre XP, Schwammenthal E, Yoganathan AP, Levine RA. Importance of leaflet elongation in causing systolic anterior motion of the mitral valve. The Journal of heart valve disease. 1997; 6(2):149-159. [PubMed: 9130123]

138. Schwammenthal E, Nakatani S, He S, Hopmeyer J, Sagie A, Weyman AE, Lever HM, Yoganathan AP, Thomas JD, Levine RA. Mechanism of mitral regurgitation in hypertrophic cardiomyopathy: mismatch of posterior to anterior leaflet length and mobility. Circulation. 1998; 98(9):856-865. [PubMed: 9738640]

139. Cavalcante JL, Barboza JS, Lever HM. Diversity of mitral valve abnormalities in obstructive hypertrophic cardiomyopathy. Prog Cardiovasc Dis. 2012; 54(6):517-522. [PubMed: 22687594]

140. Hagege AA, Bruneval P, Levine RA, Desnos M, Neamatalla H, Judge DP. The mitral valve in hypertrophic cardiomyopathy: old versus new concepts. J Cardiovasc Transl Res. 2011; 4(6): 757-766. [PubMed: 21909825]

141. Delling FN, Sanborn DY, Levine RA, Picard MH, Fifer MA, Palacios IF, Lowry PA, Vlahakes GJ, Vaturi M, Hung J. Frequency and mechanism of persistent systolic anterior motion and 
mitral regurgitation after septal ablation in obstructive hypertrophic cardiomyopathy. The American Journal of Cardiology. 2007; 100(11):1691-1695. [PubMed: 18036370]

142. Fifer MA, Vlahakes GJ. Management of symptoms in hypertrophic cardiomyopathy. Circulation. 2008; 117(3):429-439. [PubMed: 18212300]

143. Messmer BJ. Extended myectomy for hypertrophic obstructive cardiomyopathy. Ann Thorac Surg. 1994; 58(2):575-577. [PubMed: 8067875]

144. Wan CK, Dearani JA, Sundt TM 3rd, Ommen SR, Schaff HV. What is the best surgical treatment for obstructive hypertrophic cardiomyopathy and degenerative mitral regurgitation? Ann Thorac Surg. 2009; 88(3):727-731. discussion 731-2. [PubMed: 19699887]

145. Pantazis A, Hong Cheang M, Mullen M, Elliott P, McKenna W, Kumar Aggarwal S, Teresa TomeEsteban M, Reinthaler M, Delahunty N. 94 Percutaneous mitral repair in hypertrophic cardiomyopathy. Heart. 2014; 100(Suppl 3):A54-A55.

146. Cunningham MW. Streptococcus and rheumatic fever. Current opinion in rheumatology. 2012; 24(4):408-416. [PubMed: 22617826]

147. Marcus RH, Sareli P, Pocock WA, Meyer TE, Magalhaes MP, Grieve T, Antunes MJ, Barlow JB. Functional anatomy of severe mitral regurgitation in active rheumatic carditis. The American Journal of Cardiology. 1989; 63(9):577-584. [PubMed: 2919562]

148. Marcus RH, Sareli P, Pocock WA, Barlow JB. The spectrum of severe rheumatic mitral valve disease in a developing country. Correlations among clinical presentation, surgical pathologic findings, and hemodynamic sequelae. Ann Intern Med. 1994; 120(3):177-183. [PubMed: 8043061]

149. Essop MR, Nkomo VT. Rheumatic and nonrheumatic valvular heart disease: epidemiology, management, and prevention in Africa. Circulation. 2005; 112(23):3584-3591. [PubMed: 16330700]

150. Jebara VA, Mihaileanu S, Acar C, Brizard C, Grare P, Latremouille C, Chauvaud S, Fabiani JN, Deloche A, Carpentier A. Left ventricular outflow tract obstruction after mitral valve repair. Results of the sliding leaflet technique. Circulation. 1993; 88(5 Pt 2):II30-II34. [PubMed: 8222170] 

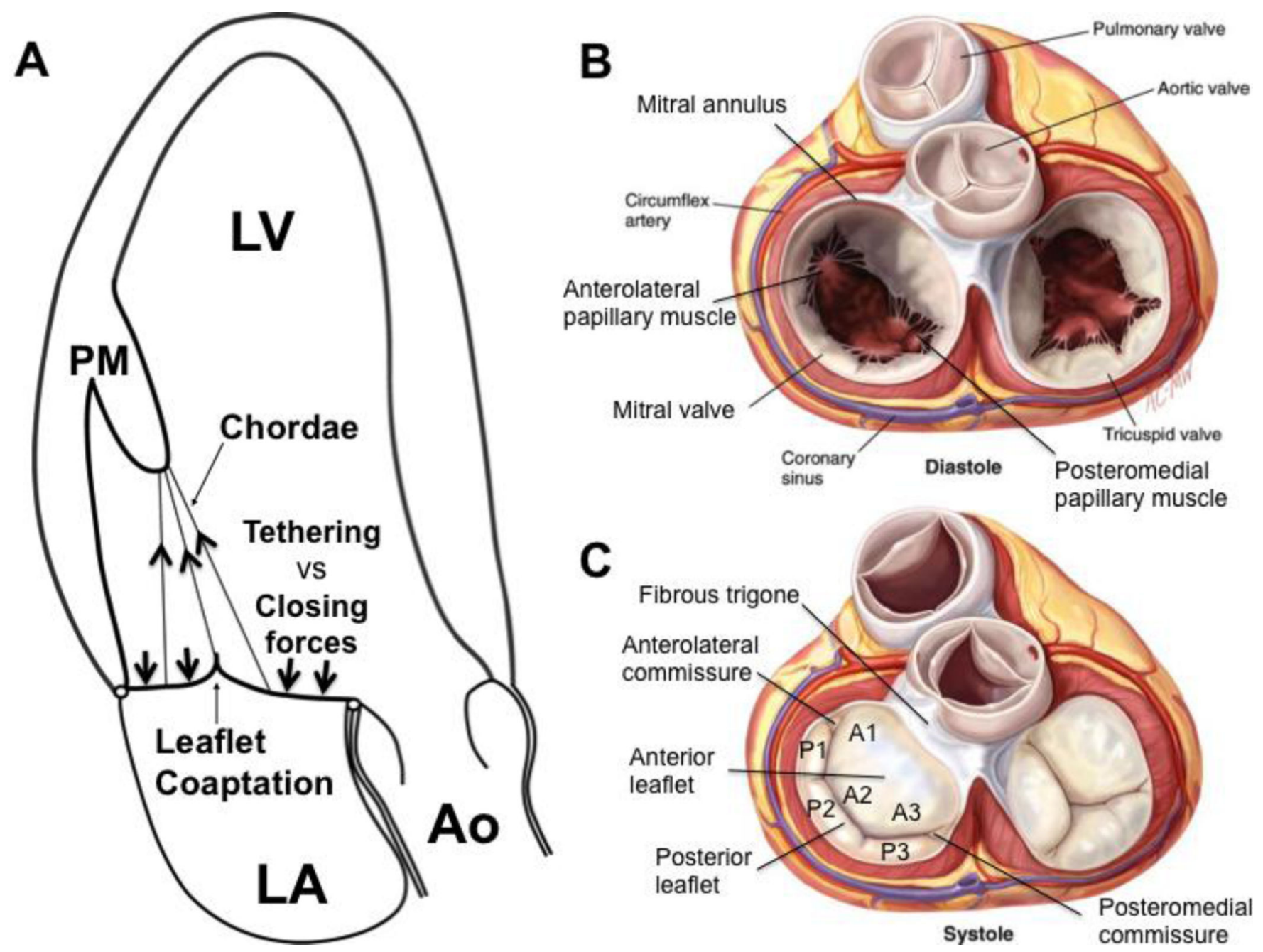

Figure 1.

A. Schematic apical long-axis view of the heart in systole (apex on top). There is normal function and spatial relationship of the left ventricular myocardium, the papillary muscles (PM), chordae, leaflets and mitral annulus. The tethering force - closing force relationship is balanced, both leaflets normally configured and concave toward the LV, and leaflet tissue coaptation sufficient preventing mitral regurgitation. B. Surgical view of the open mitral valve in diastole. C. Surgical view of the closed mitral valve is systole. (Ao, aorta; LA, left atrium; LV, left ventricle; PM, papillary muscle; Panel A adapted from Dal-Bianco et al. Anatomy of the mitral valve apparatus: role of 2D and 3D echocardiography. Cardiology Clinics. 2013 Elsevier; Panels B and C are adapted from Carpentier A et al. Carpentier's Reconstructive Valve Surgery. From Valve Analysis to Valve Reconstruction. 2010 Saunders Elsevier). 


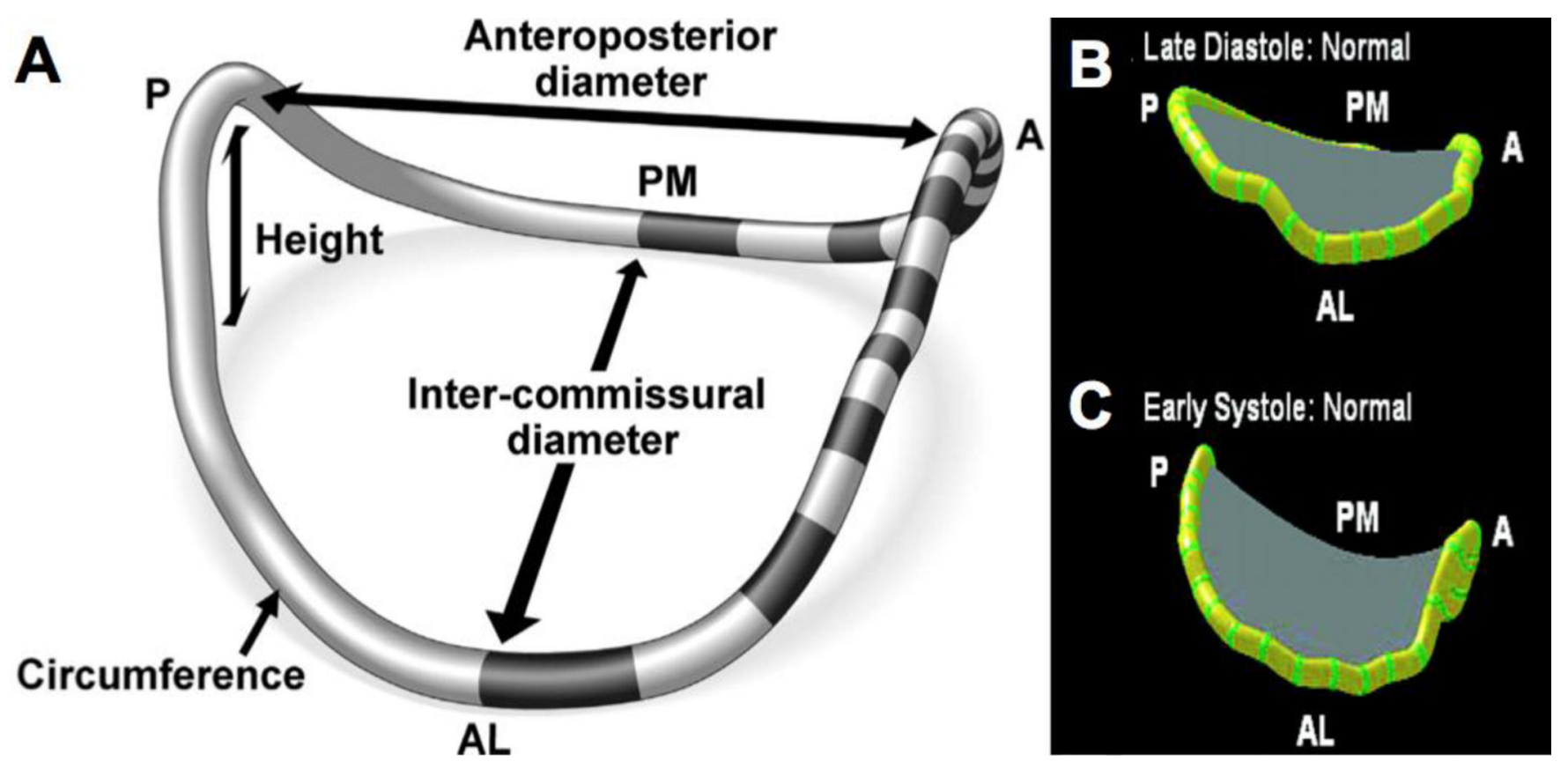

Figure 2.

A. Normal 3-dimensional mitral annulus shape: This schematic shows the complex saddle horn shape of the mitral annulus (MA). The anterior and posterior MA horns are most atrial. The commissures are close to the most ventricular nadirs of the MA. B and C.

Dynamic normal mitral annulus function. (B) Profile view of a normal MA in late diastole while maximally expanded. (C). MA sphincter-like contraction in systole promotes it's saddle shape, which minimizes leaflet stresses and reduces the MA opening area in need to be covered by the leaflets. Normal dynamic MA function therefore allows brisk LV filling in diastole and promotes optimal MV closure and coaptation in systole. (A, anterior; $\mathrm{P}$, posterior; AL, anterolateral; PM, posteromedial; Adapted from Grewal et al. Mitral Annular Dynamics in Myxomatous Valve Disease, Circulation 2010, Wolters Kluwer Health). 

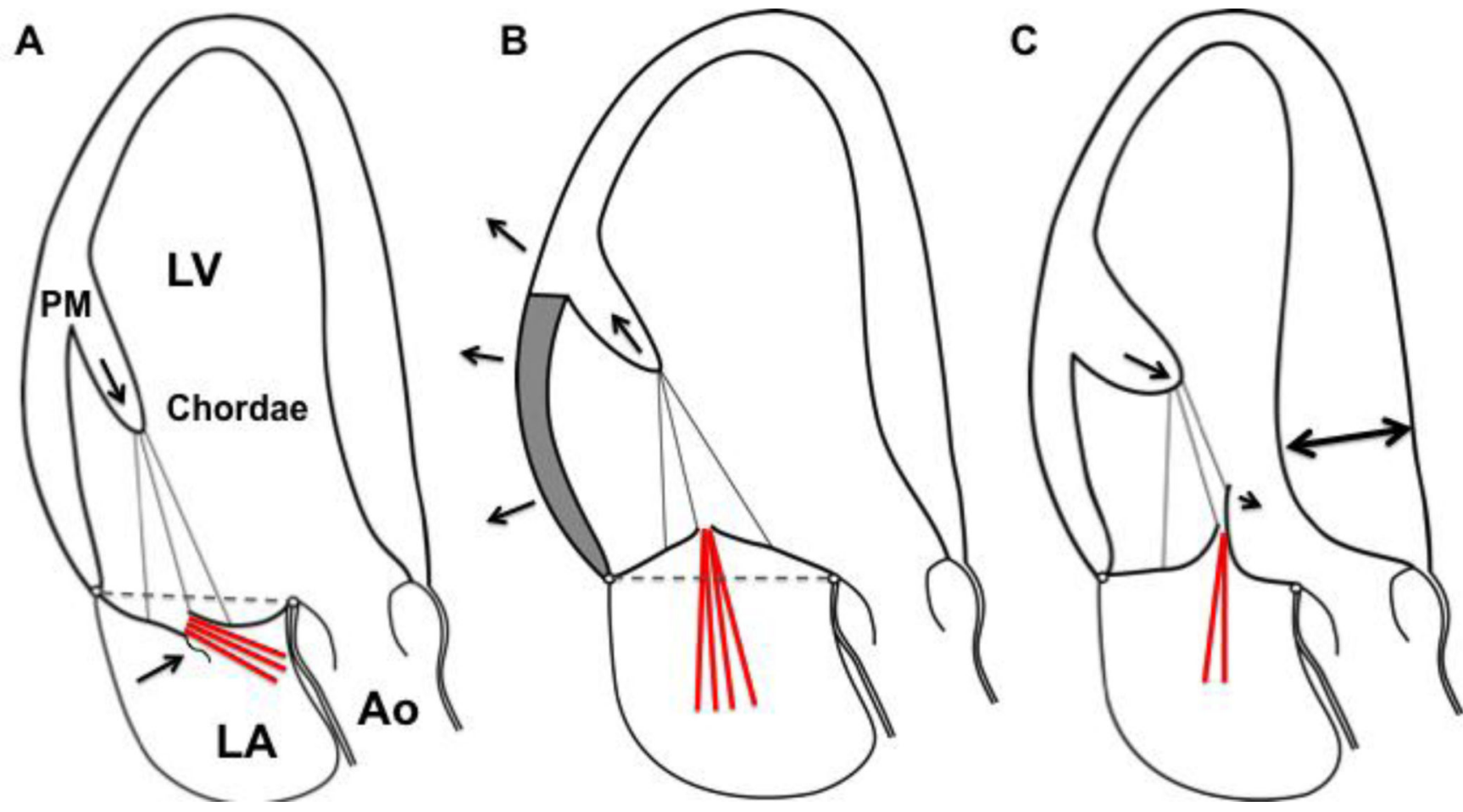

Figure 3.

A. Mitral valve prolapse with a flail posterior leaflet: The schematic shows bileaflet mitral valve prolapse with anterior directed mitral regurgitation (red lines) due to a flail posterior leaflet (arrow: ruptured chord) and loss of leaflet coaptation. Mitral valve prolapse with intact chordae is otherwise characterized by 1) leaflet coaptation that is displaced into the left atrium superior to the annular plane (dashed line), 2) superior displacement of the papillary muscle tip and 3) excessive leaflet and chordal tissue and mobility. B. Functional / ischemic mitral regurgitation: The papillary muscle is displaced posteriorly, laterally and, to the extent allowed by the chords, apically (arrow) due to left ventricular local dilatation \& remodeling (arrows) caused by ischemic / myocardial infarction (shaded area). The LV wallPM displacement tethers the mitral leaflets apically and limits coaptation. If there is not enough leaflet tissue available for coaptation to compensate for leaflet tenting (area apical to the dashed line) mitral regurgitation will develop (red lines). C. Hypertrophic cardiomyopathy: The geometry of the left ventricle and papillary muscles is altered by myocardial hypertrophy (double arrow). The papillary muscles are enlarged and displaced anteriorly (arrow) and closer to each other (not shown). This decreases intercommissural leaflet tension and moves the coaptation point and distal leaflets closer into the left ventricular outflow tract and at risk of being displaced into the LV outflow tract by bloodflow drag. If anterior leaflet displacement is severe enough and posterior leaflet apposition restricted, mitral regurgitation will occur (red lines). (Ao, aorta; LA, left atrium; LV, left ventricle; PM, papillary muscle; Adapted from Dal-Bianco et al. Anatomy of the mitral valve apparatus: role of 2D and 3D echocardiography. Cardiology Clinics. 2013 Elsevier;). 